\title{
Starting over from the landscape? Iceland between crisis and identity
}

¿Reiniciar desde el paisaje? Islandia, entre la crisis y la identidad

Luca Zarrilli Università di Chieti-Pescara (Italia)

Dipartimento di Economia

lucazarrilli@iol.it

\section{Resumen}

La fase de crecimiento de la economía de Islandia, que comenzó después de la Segunda Guerra Mundial, se interrumpió bruscamente en octubre de 2008, cuando el país fue llevado al borde de la quiebra y los islandeses se han catapultado a la llamada kreppa: la gravísima crisis financiera y social con la que Islandia se enfrentará en los próximos años. Además de los efectos económicos claramente evidentes la crisis financiera, en realidad, ha estado produciendo, en el último período de dos años, importantes consecuencias también en términos de política interna, las relaciones internacionales, el debate cultural y, en última instancia, la identidad nacional. Una explotación de los conocimientos avanzados que Islandia ha logrado en las áreas relacionadas con el análisis y la gestión del territorio y del paisaje podría ser la respuesta a la crisis desde el punto de vista de la sostenibilidad ambiental y la diversificación de negocios. Además, podría representar una reafirmación, así como una redefinición, de la identidad cultural, si tenemos en cuenta el papel que el paisaje -en el más amplio sentido de la palabra- ha estado jugando en el ámbito cultural y en las políticas de desarrollo de este país.

\section{Abstract}

The growing phase of Iceland's economy, which began after World War II, was brusquely interrupted in October 2008, when the country was brought to the verge of bankruptcy and Icelanders were catapulted in the socalled kreppa: the very serious financial and social crisis with which Icelanders will have to deal in the years to come. The financial crisis, actually, has been producing, in the last two-year period, significant consequences also in terms of domestic politics, international relations, cultural debate and even national 
identity, in addition to the highly evident economic effects. An exploitation of the advanced skills that Iceland has achieved in areas related to the analysis and the governance of the territory and the landscape could be the response to the crisis from the points of view of environmental sustainability and business diversification. Additionally, it could represent a reaffirmation, as well as a redefinition, of a cultural identity, if we consider the role that landscape - in the widest sense of the word - has been playing in the cultural sphere and in the development policies of this country.

\section{Palabras clave}

Islandia, crisis, UE, paisaje, identidad.

\section{Key words}

Iceland, crisis, EU, landscape, identity.

$$
* * *
$$

\section{Iceland between reality and stereotype}

In the collective imagery, Iceland distinguishes itself because of its geological and natural features, according to a stereotyped vision of this land (a land characterised by "ice and fire", "the wild" and "the extreme"). However, little is known of its socio-cultural context. It is generally associated with northern mythology and sagas, the singer Björk and the writer Halldór Laxness ${ }^{1}$.

With a population that barely exceeds $300,000^{2}$, and its history of relative isolation, Icelandic society is characterised by a rather elevated ethnolinguistic homogeneity (even considering immigration from abroad ${ }^{3}$ ) and well-defined identity traits, to the extent that it constitutes a sort of "laboratory" for genetic and anthropologic, as well as socio-cultural, analysis (Durrenberger and Pálsson, 1989). As Giorgio Manganelli - who went to Iceland in the 1960s as an envoy of the daily newspaper "La Stampa" - wrote,

\footnotetext{
${ }^{1}$-- Nobel prize for literature in 1955.

2.- 317,630 residents on January 12010 (source: Iceland Statistics).

3.- On January $12008,6.8 \%$ of the residents were foreign citizens, mostly Polish $(8,488)$, then Lithuanians $(1,332)$ (source: Iceland Statistics).
} 
"this land is restless and disquieting. And on this island-planet, humankind, who seems to be its guest, has a difficult, intense and unique life ${ }^{4}$ " (Manganelli, 2006: 83). He continues: "their [that is the Icelanders'] life is firstly represented by how they relate to the incredible land on which they live" (ib.: 86).

On the other hand, even the socio-economic aspects of Iceland have given rise to stereotypes ("Viking spirit", "happy isle", "arctic tiger") which obviously do not account for the complexity of the peculiar relationship between humans and the environment. According to a common understanding, which is not devoid of foundation, Iceland is a positive example of territorial "voluntarism": despite its difficult environmental context, an efficient use, even though not always sustainable, of natural resources has guaranteed not only sustenance to the population but also prosperity. And, in fact, after colonial ties had been severed with Denmark, which for centuries had relegated Iceland to subaltern status, the latter has experienced an outstanding economic development, to the extent that its gross domestic product procapita $^{5}$ and its human development index ${ }^{6}$, to cite only a few of the most common indicators, were among the first in the world. The basis for such a success was essentially due to the fishing industry. Iceland is one of the countries in the world with the highest volume of fishing ${ }^{7}$ and by far the first country if the volume is read with relation to the population. In order to understand the economic importance of this sector, it should be considered that Icelanders did not hesitate to safe-guard their fishing beds by fighting the so-called "cod wars" hesitates to enter the European Union because it wants to defend its fishing

\footnotetext{
${ }^{4}$.- Our translation from Italian.

${ }^{5}$.- 12th position in 2007, with approximately 38,000 dollars (source: CIA, World Factbook).

${ }^{6}$.- 3rd position in 2007 after Norway and Australia (source: UNDP).

7.- 16th position in 2007 with 1,399,167 tonnes of fishing (source: FAO).

${ }^{8}$.- The disputes over fishing rights, known as the "cod wars", between Iceland and the United Kingdom, started in 1958 when Iceland extended its fishing waters from 4 to 12 miles. Conflict between Iceland and the UK was resolved in 1961 with the latter accepting the new limits. The second "cod war" started in 1972 when Iceland unilaterally extended its fishing waters to 50 miles. Finally, in 1975, in order to protect and conserve the species, Iceland further extended its waters to 200 miles. A third "cod war" resulted and was resolved in 1976 by the EEC which established a 200 mile zone for all of Europe.
} 
sector from foreign fleets and Brussels policies. The production of renewal energy (geothermal and hydroelectric) also contributed to the country's outstanding economic performance. In fact, Iceland is the least polluted western country with the lowest energy costs pro-capita, and an optimal location for energy-consuming industries (like aluminium). Furthermore, the natural landscape, the nátturufegurð, because of its spectacular features, is a formidable resource for the tourist industry, which is rapidly expanding, as well as a national "calling card" for attracting foreign investment from the movie industry.

However, the growing phase of Iceland's economy, which began after World War II and was brusquely interrupted in October 2008, was not only due to the exploitation of the natural environment (fishing areas, geothermal fields, rivers and natural landscape). In fact, since the mid 1990s, the newly privatized banking sector in general, and in particular the so-called "creative" finance sector, experienced a growth which may well rightly be defined as abnormal and beyond the capacity of the Central Bank to intervene, an example of which is the foreign debt (largely due to the foreign assets of the banking sector), which by the middle of 2008 was equal to 10 times the gross domestic product. Easy access to credit therefore inevitably implied personal consumption levels that were above the population's real earning and expenditure capacity. The impression of opulence was certainly ephemeral as it was not only based on the production of wealth but also, considerably, on access to credit.

At the same time of the global financial crisis - and for reasons that are partly connected to it, partly specific to Icelandic situation - the macroscopic financial imbalance that was created brought the country to the verge of bankruptcy and opened the way for the so-called kreppa ${ }^{9}$ : the very serious financial, economic, employment, political and social crisis ${ }^{10}$ in which Islanders were catapulted into from one day to another. As has been correctly observed, the kreppa, further to its literal meaning of crisis, "actually connotes something more: the roar of a volcano perhaps; the approach of a catastrophe"

\footnotetext{
${ }^{9}$.- Literally: crisis, depression, contraction.

${ }^{10}$.- In 2009 the gross domestic product decreased of $6.5 \%$, while the unemployment rate increased from $2.7 \%$ in 2007 to $7.2 \%$ in 2009 (Source: Statistics Iceland).
} 
(Boyes, 2009: X). Another stereotype which is quite diffused is that of Icelanders used to catastrophes, which have decimated the population over the centuries and periodically taken shape as eruptions, avalanches and jökulhlaup ${ }^{11}$. However, the notion of catastrophe in terms of financial default is novel for Iceland, further to being an event which Icelanders will have to deal with in the years to come. The financial crisis has been producing, in the last two-year period, significant consequences also in terms of domestic politics, international relations, cultural debate and even national identity, in addition to the highly evident economic effects; all of which will be illustrated in discussion to follow.

\section{The landscape picture}

Landscape as an identity factor as well as a resource to exploit: that is certainly not a new subject nor an original one in geographic research, but in Iceland it assumes peculiar features that may deserve deeper investigation, especially in the context of the current financial crisis. Before entering the question - that will be discussed in the last paragraph of this paper -, I would like to entrust a description, be it brief and imaginary, of the complex Icelandic landscape picture to the words of some witty observers. Such a description is certainly not a simple job, if we consider the variety, heterogeneity, extravagance, changing nature, strength and striking quality of its object. In her travel report Valeria Viganò writes: "Iceland does not only recall literature, it is an open air museum [...]. In this land there are no pictures displayed inside or outside a museum, for art is the surrounding nature. [...] In a kaleidoscopic succession of absolutely real views with gigantic proportions were they not reduced from our human sight, we pace through the biggest though tightened up and various museum of natural and landscape paintings in the world. In a few dozen kilometres we see seascapes, hills, mountain tops covered with snow or smoking, boats lost on the horizon ${ }^{12}$ " (Viganò, 2004: 41). In fact the impression one takes back after a brief voyage to Iceland is one of a both extraordinary and quick changing landscape, an abrupt and unpredictable switching between unique environmental pictures that are strong and lunar

\footnotetext{
${ }^{11}$.- Flooding caused as a consequence of the eruption of a volcano embedded under a glacier.

12.- Our translation from Italian.
} 
and do possess an almost upsetting beauty. Manganelli gives us an effective report of the intrinsic geologic and primeval quality of Icelandic landscape: "First of all, there's the initial, pre-human structure, to the limits of the planetary, that this island offers where the behavioral rules that made earth a decently stable planet do not seem to hold. This childish land has all the oddities, the aphasics rages, the faintnesses, the dreamy extravagances that the earth has not yet definitely taken in and tamed. Iceland is a volcanic land, totally volcanic, a continuous tremble, holes burst open everywhere admitting to bubbling night rivers and signs saying, in a polite English, "do not come near, you could fall inside it in case of earthquake» do cause an hysterical

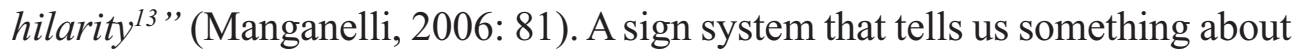
Icelandic attitude towards environmental risks: better not play with nature, but no hysteria! Like Manganelli even Piero Citati, the author of a new reportage for the Italian newspaper "La Repubblica", claims: "When I came back to Rome, friends asked me: "Is Iceland a beautiful place? Did you have fun?» Now, Iceland does not belong to the category of beauty: beauty is a divine thing, or even a human thing or of a nature similar to man or god; while Iceland does not know our gods, maybe it doesn't know any god, not even is it part of nature, as Manganelli used to say. [...] At the beginning of twenty first century, one finds the origins of earth, the end of the universe, the metamorphosis of volcanoes, the nightmares of nature and men, the hereafter Hades, the abyss, the miracles of water and fire ${ }^{14}$ ". (Citati, 2004: 29). Here again, one finds the two topics of the "drama" of Icelandic landscape and its "being other" from what is human or simply referable to a familiar world, a world we usually know and experience. Iceland and its landscape seem thus to escape not just the stereotypical definitions, but even the usual evaluation and judgment patterns, no matter if we're talking about aesthetics or geophysics.

\section{Salient phases of the crisis}

The intent of this paper is not to investigate the causes of the crisis in Iceland. However, it is necessary to briefly allude to the salient phases which

\footnotetext{
${ }^{13}$ - - Our translation from Italian.

${ }^{14}$.- Our translation from Italian.
} 
characterised it for a better understanding of the events and effects which followed.

The first signs of the crisis appeared in 2006 and, even then, there was talk of the "Geyser Crisis". In fact, since 2005, Robert Aliber from the University of Chicago defined the situation in Iceland as a "perfect bubble" (Kindleberger and Aliber, 2005) and forecast its bursting. This occurred in October 2008, when Iceland was overwhelmed by the crash of the world stock exchanges which was then followed by the American subprime loans crisis. At this given point in time the "happy isle" and "artic tiger" metaphors were replaced with the metaphors of "fallen paradise" and "bankrupt isle" by the mass media.

Primarily, Iceland's currency must be taken into consideration. The national currency (the krona) had, since the very start of the $21^{\text {st }}$ century, been strongly exposed to international fluctuations, which were the result of high interest rates (5-6\%, against $2-4 \%$ in the Euro-USA area and $0-1 \%$ in Japan), that attracted money flow from global markets to finance Iceland's public debt, shares and bonds. For example, it was particularly attractive for international speculators to obtain loans in Japan and re-invest in Iceland. In order to discourage the population from going into debt, the Central Bank raised the interest rates and consequently sparked off a vicious circle: the more interest rates increased, the more Icelandic debt bonds became inviting and thus attracted capital, which meant that interest rates became increasingly higher, and in September 2008 reached 15,5\%.

The enormous flow of money and lack of control mechanisms on financial transactions permitted the banking system and groups of entrepreneurs ${ }^{15}$ who were connected with it to invest abroad without restraint: between 2003 and 2007 foreign debt of the three main banks increased from $200 \%$ to $900 \%$ of the GDP ${ }^{16}$. The state of indebtedness of Icesave - the

\footnotetext{
${ }^{15}$.- Essentially they are the Samson, Baugur, Fons, Oddaflug, Bakkavor, Exista and Samskip groups, who are considered oligarchs in the Russian sense as they are very close to political and financial powers and are defined by the term "new vikings", given their sharp propensity for "company raids" abroad (Hamleys, Saks, Bang \& Olufsen, Woolworths, American Airlines, EasyJet, Finnair, West Ham United, XL Leisure, House of Fraser are among the main companies involved by Icelandic takeover).

16.- Richard Thomas, financial analyst for Merril Lynch, defined Icelandic banks «too fast, too young, too much, too short, too connected, too volatile», (cited in Jónsson, 2009: 123).
} 
infamous on-line Landsbanki financial product - has been at the centre of political debate in Iceland and particularly concerns British and Dutch investors ${ }^{17}$.

In October 2008, Iceland was exposed to much turmoil because of a combination of factors, namely: the tightening of credit in international money markets due to the international financial crisis; the race of foreign investors to withdraw from Icesave $e^{18}$; the persistent weakening of the krona (in fact, in February 2008 The Economist considered the currency to be the most overvalued in the world); the impossibility of intervention by the Central Bank of Iceland due to the macroscopic unbalance between the debt of the banks, estimated to be over 75 billion euro, and the exchange reserves of the country, which were equal to 5 billion euro.

Frantic events ensued that disrupted the economic and financial situation in the country to the extent that the then Prime Minister Geir Haarde overtly announced the risk of national bankruptcy ${ }^{19}$. The government, upon suggestion by the International Monetary Fund, nationalised the three banks between October 7-10, assumed all responsibilities and the consequent explosion of the public debt. On October 9 the krona was suspended from trading because its value dropped by $78 \%$ in only a few hours. When the Icelandic stock-exchange, composed by $73 \%$ of shares connected with credit institutions involved in the crisis, re-opened for trading on October 14, after a week's suspension, it lost about $77 \%$ of its entire capitalization. On October 20 2008, after a loan proposal of 4 billion euro from Russia never eventuated and faded into obscurity, the International Monetary Fund put forward an alternative plan which consisted in a direct loan of one billion dollars and a

\footnotetext{
${ }^{17}$.- 300,000 British and 125,000 Dutch, as well as approximately a hundred UK public entities for a total debt which is today estimated at 3.9 billion euro.

${ }^{18}$.- On October 7 the English site for Icesave read: "We are not currently processing any deposits or any withdrawal requests through our Icesave internet accounts. We apologise for any inconvenience this may cause our customers. We hope to provide you with more information shortly." (www.icesave.co.uk).

${ }^{19}$.- "There is a very real danger, fellow citizens, that the Icelandic economy in the worst case could be sucked into the whirlpool, and the result could be national bankruptcy.... If there was ever a moment when the Icelandic nation needed to stand together and show fortitude in the face of adversity, then this is the moment.... God bless the Icelandic nation!" (G. Haarde, from his "Speech to the Nation" on October 6 2008, reported in Jónsson, 2009: 170-171).
} 
further five billion dollars from central Scandinavian and Japanese banks. During 2009 the situation stabilised, but the country's finances were in a dismal state: in July 2009 did the nation draw breath and avoid bankruptcy for the umpteenth time only thanks to a loan of a further 2 billion euro provided by the International Monetary Fund.

The case of Iceland, rather than of its entity -which is considered marginal by the global financial system ${ }^{20}$-, is emblematic of the dynamics involved and the means via which the crisis took shape, so much so that, nowadays, the expression "Going Iceland" is indicative of the collapse of an entire national financial system.

\section{Political repercussions}

Initially the Icelandic population was understandably panic stricken by the news following the events of October 6 2008. There were long queues at banks, stocking up of food supplies and hoarding of precious objects and luxury goods to maintain buying potential which was no longer guaranteed by the national currency. However, indignation and public protest followed the panic which evolved into what was to be defined as the "kitchenware revolution" ${ }^{21}$. Initially it was held only on Saturdays but later on a daily basis. Many citizen groups ${ }^{22}$ demonstrated increasingly in Parliament Square to demand the government's resignation and new elections.

Tension reached its limit on January 202009 and the days immediately following, when protests degenerated into conflict with the police. However, these incidents provoked the desired effect and the government was forced to resign. A caretaker government steered the country towards an early election on April 292009 and a centre-left coalition formed by the Social Democratic Alliance and the Green Party were elected to government after a period of 18 years of uninterrupted rule by the centre-right coalition.

The extent of the international ramifications of the crisis can be gauged by the fact that the anti-government protest was furthered by resentment

\footnotetext{
${ }^{20}$.- "From the international perspective, Iceland as a country was not too big to fail" (Jónsson, 2009:136).

${ }^{21}$.- It was so defined because participants in demonstrations rattled their kitchen utensils in protest. 22.- About 6,000 people were present in the square at the peak of the protests, which is a low figure when taken for its absolute value, but it does represent $2 \%$ of the entire Icelandic population.
} 
against the executive of the United Kingdom in what may be defined as the incipit to the Icesave issue. According to the British, the nationalisation of the Landsbanki would have made the government of Iceland responsible for the damages owing to clients of Icesave. The intention of Reyjavík, in the aftermath of October 6, to give priority and guarantee to national investors ${ }^{23}$, induced the Brown government to put into

Effect the financial clauses foreseen by anti-terrorism legislation ${ }^{24}$, introduced after the September 11 attacks, in order to freeze Icelandic bank and government assets in the United Kingdom, thus making any financial transaction to and from Iceland impossible and contributing in this way to worsening the already very difficult financial situation of the country. Iceland considered British reaction a very grave and unjustifiably hostile act; it was also considered excessive by analysts and probably connected to British domestic politics. The entire nation was paralleled to a terrorist organisation ${ }^{25}$. Instead, responsibility for the situation was to be attributed to a restricted and inter-connected group of bankers, politicians and oligarchs (who were also in cahoots with their counterparts in the UK) as well as to the inadequate EU control mechanisms on transnational financial operations ${ }^{26}$.

\footnotetext{
23.- On October 7, Arni Mathiesen, the then Iceland's Minister for Finances, stated the following in a telephone conversation with Alistar Darling, Minister for Finances in the UK at the time, "We need to secure the domestic situation before I can give you any guarantees for anything else" (reported in Boyes, 2009: 167). Such a declaration, as is evident, does not necessarily represent a refusal to recognise the rights of foreign investors to seek damages, as instead the British government maintained. In fact, in a radio interview on the BBC on October 8 Darling declared: "The Icelandic government, believe it or not, has told me yesterday they have no intention of honouring their obligations here" (reported in Jónsson, 2009: 184).

24.- The 2001 "Anti-Terrorism, Crime and Security Act". The application of this law to States which are not involved in terrorist activity is without precedent.

${ }^{25}$.- "To the Icelanders, though, it was tantamount to a declaration of war. At one stroke Britain had placed the island on the same level as Al Qaeda, even though it was a fellow NATO partner" (Boyes 2009: 174). InDefense was started on this occasion. It is a citizens' rights association which organised an on-line petition ("Icelanders are NOT terrorists") to protest against the adoption of anti-terrorist legislation by the British government. The petition collected 83,000 signatures.

${ }^{26}$.- "The fact that the Icelandic Fund for the Protection of Deposits contained 1\% of the real total deposits was perfectly legal: in other words EU regulation did not take into consideration a systemic crash of the banking system. Furthermore, EU regulations did not even foresee, in case of bankruptcy, that insurance of deposits belonging to a private bank should become the responsibility of the government of that specific country where the bank has its official headquarters" (Our translation from Italian) (Rossi, http://www.eurasia-rivista.org/3301/lislanda-ed-il-referendum-icesave-previsioni-sul-risultato
} 
On June 52009 the new Icelandic government signed a bilateral agreement with the United Kingdom and the Netherlands for a solution to the Icesave problem with the intent of facilitating funding from the International Monetary Fund and accelerating entry to the European Union, which we shall see is a crucial point on Reyjavík's political agenda. On the basis of these agreements, the United Kingdom and the Netherlands put forward the money required to pay damages to British and Dutch investors, money which Iceland was to pay back at set times and via set means ${ }^{27}$ as defined by a law approved by the Icelandic Parliament on December 30 2009. However, the law was not enacted by the President of the Republic Olafur Ragnar Grímson, who wanted to take into account the petition ${ }^{28}$ signed by 56,000 citizens of Iceland (equal to $23 \%$ of the electorate), which requested that the financial strategy plan not be approved because it was excessively onerous and unjustifiably lucrative for the British and Dutch governments ${ }^{29}$. In compliance of Article 26 of the Constitution, a referendum was called so that Icelanders themselves could decide on the matter. The referendum was conducted on March 62010 with an overwhelming and foreseeable victory ( $93.2 \%$ of voters) by the faction against the conditions for settlement of damages foreseen by the Icesave agreement.

\section{Towards Europe?}

On May 31 2005, at the Centre for European Policy Studies in Brussels, the then Minister for Foreign Affairs Davíð Oddson ${ }^{30}$ concluded his intervention on Iceland's entry to the European Union: "We Icelanders are most certainly pro-European. We want close cooperation with all those who

\footnotetext{
${ }^{27}$.- By and large in 14 years at a rate of $5.5 \%$.

${ }^{28}$.- Even in this case InDefence promoted the petition.

${ }^{29}$.- "he proposed interest rate of $5.5 \%$ is particularly unfair, given that the UK's Financial Services Compensation Service has, according to the UK Treasury, "financed its payout [to UK depositors] through a loan from the Bank of England." The Treasury does not disclose the rate of interest on this loan - a rate over which it had absolute discretion. The Bank of England's base rate is today $0.5 \%$ (1.5\% in January, 2009). The ECB's base rate was $2.0 \%$ in January 2009 , yet the Netherlands government had even greater audacity in seeking, initially, interest at $6.7 \%$ !" (Pettifor, http://advocacyinternational.co.uk/?p=813).

30.- Davíð Oddson had been Prime Minister of the centre-right government from April 301991 to September 152004.
} 
adhere to the high European ideals of prosperity, peace and freedom. We follow those aims but have for ourselves chosen a route outside the European Union - a pragmatic one but not only because of the fish! We take this route because it is beneficial for us and without harm to anyone else". ${ }^{31}$

These words are indicative of the distance that the centre-right coalition, and perhaps more generally Icelandic society, has always taken with respect to EU integration: to limit it to trade exchange and human mobility. In fact, Iceland adhered to the Council of Europe in 1950, EFTA ${ }^{32}$ in 1970, EEA ${ }^{33}$ in 1994 and the Schengen Agreement in 1996, but only recently did it take into consideration entry to the EU. Reasons are clear: entry to the EU implies observing Community fishing policies and rules, which presumably means that the driving sector of the economy would be negatively affected, while as an EEA country Iceland does not have to observe EU fishing policies and the matter is governed by bilateral agreements in an ad hoc manner.

Instead, the new Icelandic government lead by Jóhanna Sigurðadóttir immediately adopted a pro-European stance by putting entry to the European Union high on the country's political agenda. In fact, already by July 2009, that is only after two months of Sigurðadóttir took up her post, the Icelandic government presented a formal request for entry to the EU which was well accepted by the Swedish Presidency and by the then European Commissioner for Enlargement Olli Rehn"34. In the words of the premier: "Iceland's application for EU membership represents a clear strategy for the country's direction and vision for the longer term. The application and the reception it has received send a clear and reassuring message to the outside world" 35 . The government of Iceland seems to have been inspired by considerations relating

\footnotetext{
${ }^{31}$ - http://www.ceps.be/

32.- European Free Trade Association, a regional trade agreement which is today constituted by Iceland, Lichtenstein, Norway and Switzerland.

33.- European Economic Area, or European Economic Space, instituted on January 11994 after the agreement between EFTA and the EU with the objective of allowing EFTA countries to participate in the common European market without joining the Union. Via its affilation with EEA, the Icelandic banking sector expanded significantly.

34.- At a lecture at the University of Iceland Olli Rehn underlined the high degree of integration that Iceland had reached with European institutions, which should relatively facilitate reception of the acquis communitaire and rapid joining process.

${ }^{35}$.- http://www.euractiv.com/en/enlargement/eu-iceland-relations/article-187881
} 
to prestige and international credibility more than mere economic preoccupations ${ }^{36}$ : after decades of relative "Euroskepticism" - only mitigated by the accession to the abovementioned institutions - and following the loss of esteem caused by the financial crisis and the related events, Iceland should take a definitive step towards Europe and integration into a wider economic and political context.

The current government has the above intentions. But, there are at least two obstacles to Iceland's entry to the EU: public opinion and the result of the March 62010 referendum. A hasty analysis of the effects of kreppa could have indicated a tendency for public opinion to be pro-European as an emotional response to uncertainty and fear for the future. Instead, according to public opinion, it appears that the opposite is true: if in $200543 \%$ of Icelanders were favourable to entry to the European Union, today that figure has decreased to $33,2 \%$, while those against have increased from $37 \%$ to $56 \%{ }^{37}$. A conservative attitude - in the economics, as well as in the international relations - seems to be steering Icelandic society in the aftermath of the crisis and giving way to a lessened pro-European spirit. This vision appears to be confirmed by the result of the referendum: it can be argued that people voted against what was considered as an economic sanction, but it was quite clear that such a vote would have represented a further obstacle for Iceland's entry to the EU (because of a possible boycotting by the United Kingdom and the Netherlands, unsatisfied with the rejection of the Icesave agreement) and, more generally, would have pushed the country further towards international isolation.

\section{Starting over from the landscape?}

It seems as though Iceland, while experiencing the kreppa, is at the crossroads: should it accelerate European integration and entry to the EU and accept the consequent potential reduction of fishing activity in exchange for the prospect of political and financial support which would be guaranteed by

\footnotetext{
${ }^{36}$.- However, it should be taken into consideration that the potential adoption of the euro in Iceland is considered positive by many since it would constitute a form of economic stability and protection from serious currency problems: the Icelandic currency is one of the smallest in the world and therefore the risk of attack from international speculators is high.

${ }^{37}$.- Surveys carried out in August 2005 and February 2010 by the Capacent-Gallup Institute.
} 
the status of EU member country, not to mention the return in terms of international image? Or, should it continue with a moderate isolationist politics, knowing that it can mainly rely on natural resources, fishing above all, but also energy production, which inevitably takes its toll on the environment and the landscape ${ }^{38}$ ?

The choice is also an issue of national identity, under various profiles. Above all, a strictly political aspect must be considered: the European option is seen by many as comparable to relinquishing sovereignty, given that Iceland only became fully independent from Denmark in $1944^{39}$. Furthermore, the historical-economic aspect cannot be ignored. The development of trade and entrepreneurial activity associated with fishing - which was initially only a seasonal subsistence activity integrating the income derived from agricultural activity and livestock - since the end of the $19^{\text {th }}$ century has deeply transformed the structure of Icelandic society. The hegemonic role traditionally afforded to land owners who had trade relations with Denmark was taken over by an emerging class of fishermen-shipyard owners. Consequently, settlements and economic activity moved towards the coast. Therefore, the transition to fishing related activity, to a certain extent, ushered Iceland into modernity and away from domination by the alliance between land owner élite and Danish merchants. National identity was in fact re-defined: "political mobilization, national self-determination, capital investment, wage labour, and the hope of a prosperous future all developed together to link fishing, the sea, prosperity, national, and individual independence into a single gestalt in terms of which Icelanders now understand their recent past and present. These images of Icelandicness are replacing the previous more bucolic ones based on livestock farming" (Durrenberger, 1996: 184). And there's no doubt that the fishing linked activities have shaped and still shape in a very deep way the "cultural" landscape of the country.

\footnotetext{
${ }^{38}$.- For example, this is the case of the hydroelectric plant in Kárahnjúkar to the east of the country, which was built to supply energy to a single aluminium production plant owned by the US multinational company Alcoa.

39.- A de facto independence from Denmark had already been reached between the end of the 19th and the beginning of 20th century: in 1874 Denmark granted Iceland home rule, which was expanded in 1904. With the Act of Union of 1918 Denmark recognized Iceland as a fully-sovereign state joined with Denmark in a personal union with the Danish king.
} 
On the other hand, and what follows is not necessarily a contradiction, there is a cosmopolitan component in Icelandic society (which is not necessarily pro-European), which contrasts the "insular" spirit and the conservative political and economic "status quo" which was created after independence: "through the ages, the nation has swung between the extremes of isolation and openness. Years spent in withdrawal from the world have been followed by outbursts of a yearning to aggressively pursue its riches" (Jónsson, 2009: 9). In a certain sense, the audacity, and one might even say the unscrupulous manner, in which Icelandic banks and entrepreneurs operated in foreign markets, can be considered as indicative of this component: recall to Viking origins is far too obvious.

National identity is not static: it is formed and transformed as a consequence of events that have taken place in a nation and Iceland is not an exception to this notion. As Gísli Pálsson and Paul Durrenberger maintain, "Iceland is a modern nation and a site for the manufacture of nationalism" (Pálsson and Durrenberger, 1996: 2) and therefore it can be understood how, in the recent history of this people, political and economic aspects have contributed to building an identity based on some strongholds: political and economic independence, modernity, prosperity and individualism. Given this scenario, the notion of Europe appears too broad, a mare magnum which risks weakening a sense of national identity which is to be safeguarded. On the other hand, the notion of Europe appears to be somehow "claustrophobic" to Icelandic nation, which is culturally and geographically at the helm of Nordic western civilisation, half way between Europe and America, but projected beyond the Atlantic.

Viewed in the above light, the issue of belonging to the EU and the image, or images, that Icelanders have of Iceland in actual fact appear incompatible. However, in our opinion, Iceland does not only represent fishing and insularity on the one hand and financial creativity and cosmopolitanism on the other. It may also - and may above all - be "landscape", in a geological, telluric, but also cultural sense. Previously (Finocchietti and Zarrilli, 2007a, 2007b), we emphasised that in Iceland, similarly to other places, the territory and the landscape become identity defining factors and permeate many aspects of society: from the political to the economic; from aspects relating to 
entertainment to the $\operatorname{arts}^{40}$, from design to video-clip ${ }^{41}$. For the painter Helgi Thorgils Fridjónsson "the artist's mind is linked to sense of the sublime that nature alone can give and to a specific religious or divine experience which you can find in the Icelandic highlands" (Ólafsdóttir, 2001: 34), while for the photographer Olafur Elíasson Icelandic nature is the departure point of his research. He explains: "I could use music or film, but I use Iceland, because I know it and my personal content comes from there. Otherwise I would just be like a physicist investigating natural phenomena" (ib.: 36). These are simple examples which reveal another dimension of being Icelandic, of "Icelandiceness": namely, the "special" relationship with the natural environment and the landscape that, even according to my personal experience, cannot be reduced to a mere stereotype. The fact that it is not a matter of a simple stereotype or a fact of "folklore" is shown by the advanced, often avant-garde, skills that Iceland has achieved in areas related to the analysis and the governance of the territory and the landscape: geothermal science applications and, more generally, production of energy from renewable sources; management of natural hazards; landscape analysis and management; nature oriented tourism and the multitudes of its facets, including thermal tourism in geothermal areas; analysis and planning of the territory; organic agriculture and biodiversity; natural cosmetic and therapies. An exploitation ${ }^{42}$

\footnotetext{
40.- "In Icelandic art the landscape is an important subject to portray as well as a determining factor for the cultural identity of the Icelandic people. Modern art developed in Iceland at the end of the last century when living conditions were improving and with political independence of the nation. Nature was the main object of art at the time." (Our translation from Italian) (Ólafur Kvaran, 1999:9).

${ }^{41}$.- The video clip of the song Joga is a particularly eloquent example. It is from the album Homogenic (1997) by Björk and was directed by Michel Gondry.

${ }^{42}$.- Náttura (http://nattura.info/), conceived by the singer Björk, is such an example. It is a project aimed at the start-up and networking of micro-companies that work in different sectors, all connected with the sustainable exploitation of environment and nature. In the words of Björk, "Iceland can be more self-sufficient and more creative and have an approach that is more 21st century than 19th century. [...] We can use this economical crisis to become totally sustainable, and teach the world all we know about geothermal power plants. It may take longer to build and deliver profits, but it is solid, stable and something that will stand independent of the roller coaster rides of Wall Street and volatile aluminium prices. And it will help Iceland do what it is best at: being a gorgeous, unpredictable force of nature" (Björk, "After financial meltdown, now it's smeltdown. The men who made Iceland go cap in hand to the IMF are now bent on ruining its landscape", Times On Line, 28 October 2008. http://www.timesonline.co.uk/tol/comment/columnists/guest_contributors/article5026175.ece).
} 
of the all of the above, possibly according to the pattern of production districts and to the logic of territorial specialization, could be the response to the crisis from the points of view of environmental sustainability and business diversification. Additionally, it could overcome the "Europe dilemma"43 and represent a non-conservative reaffirmation - as well as a creative redefinition - of a cultural identity.

\section{Bibliographical references}

Benediktsson, K. (2009): "The Industrial Imperative and Second (Hand) Modernity", in T. Nyseth and A. Viken (eds.): Place Reinvention. Northern Perspectives, Farnham, Ashgate: 15-31.

Boyes, R. (2009): Meltdown Iceland. How the Global Financial Crisis Bankrupted an Entire Country, London, Bloomsbury.

Citati, P. (2004): Viaggio in Islanda, Roma, La Repubblica, 23 August.

Durrenberger, E. P. (1996): "Every Icelander a Special Case”, in G. Pálsson and E. P. Durrenberger (eds.), Images of Contemporary Iceland. Everyday Lives and Global Contexts, Iowa City, University of Iowa Press: 171-190.

Durrenberger, E. P. and Pálsson, G. (eds.) (1989): The Antrhopology of Iceland, Iowa City, University of Iowa Press.

Einarsson, M. (1996): "The Wandering Semioticians: Tourism and the Image of Modern Iceland”, in G. Pálsson and E. P. Durrenberger (eds.): Images of Contemporary Iceland. Everyday Lives and Global Contexts, Iowa City, University of Iowa Press: 215-235.

Einarsson, N. (1996): "A Sea of Images: Fishers, Whalers, and Environmentalists", in G. Pálsson and E. P. Durrenberger (eds.), Images of Contemporary Iceland. Everyday Lives and Global Contexts, Iowa City, University of Iowa Press: 46-59.

Finocchietti, E. and Zarrilli, L. (2006): "Landscape Culture and Territorial Development: The Case of Iceland", Revista Romana de Geografie Politica, Universitatea din Oradea (Romania), 2: 47-55.

\footnotetext{
43.-A choice of this type would be perfectly compatible with entry to the EU, and in fact it would be also fostered in terms of EU funding for this kind of activities.
} 
Finocchietti, E. and Zarrilli L. (2007a): "Cultura e paesaggio in Islanda: fattori identitari e traiettorie di sviluppo”, in L. Zarrilli (ed.): Lifescapes. Culture Paesaggi Identità, Franco Angeli, Milano: 39-52.

Finocchietti, E. and Zarrilli, L. (2007b): "Paesaggio naturale e politiche di sviluppo territoriale in Islanda", in P. Persi (ed.): Recondita armonia. Il Paesaggio tra progetto e governo del territorio. Atti del III Convegno Internazionale Beni Culturali, Urbino, 5-6-7- ottobre 2006, Istituto Interfacoltà di Geografia - Università degli Studi di Urbino "Carlo Bo", Urbino: 116-124.

Freeman, J. (ed.) (1989): Landascapes from a High Altitude. Icelandic Art 1909-1989, London, Lund Humphries.

Icelandic Tourist Board (2004): Tourism in figures, Reykjavík.

Jónsson, A. (2009): Why Iceland? How One of the World's Smallest Countries Became the Meltdown's Biggest Casualty, New York, McGraw-Hill.

Kindleberger, C. P. and Aliber, R. Z. (2005): Manias, Panics and Crashes: A History of Financial Crises, Oxford, Macmillan.

Kvaral, O. (1999): "Presentazione", in La metamorfosi della natura. Quattro pittori islandesi, Reykjavík, Galleria Nazionale di Islanda, n. 24: 9-10.

Kvaral, O. and Kristjánsdóttir K. (eds.) (2001): Confronting nature. Icelandic Art of the $20^{\text {th }}$ Century, Reykjavík, Oddi Printing.

Lacy, T. G. (1998): Ring of Season. Iceland - Its Culture and History, Reykjavík, The University of Iceland Press.

Manganelli, G. (2006): L'Isola Pianeta e altri settentrioni, Milano, Adelphi. Ministry for the Environment (2002): Welfare for the Future. Iceland's National Strategy for Sustainable Development 2002-2020, Reykjavík.

Ministry for the Environment, Ministry of Fisheries, Ministry for Foreign Affairs (2004): The Ocean. Iceland's Policy, Reykjavík.

Ólafsdóttir, A. (2001): "Visions of Nature in Icelandic Art", in Ó. Kvaral and K. Kristjánsdóttir (eds.): Confronting nature. Icelandic Art of the $20^{\text {th }}$ Century, Reykjavík, Oddi Printing: 23-38.

Pálsson, G. and Durrenberger, E. P. (eds.) (1996): Images of Contemporary Iceland. Everyday Lives and Global Contexts, Iowa City, University of Iowa Press.

Persi, P. (1994): "L'Islanda: terra di calamità, terra promessa", in G. Orombelli, C. Smiraglia, R. Terranova (eds.): Verso una nuova geografia delle terre 
polari: sintesi e prospettive, Roma, Società Geografica Italiana: 71-80.

Viganò, V. (2004): Siamo state a Kirkjubcejarklaustur, Vicenza, Neri Pozza Editore.

Waage, E. R. H. and Benediktsson, K. (2010): "Performing Expertise: Landscape, Governmentality and Conservation Planning in Iceland", Journal of Environmental Policy \& Planning, Abingdon, 1: 1-22.

\section{Author's biography}

Luca Zarrilli is graduated in Economics at the University "Federico II" of Naples. He is Ph.D. in Political Geography (University of Trieste, Italy) and Associate Professor of Political and Economic Geography in the Faculty of Economics of the University "G. D'Annunzio" of Chieti-Pescara (Italy). He visited Iceland several time in the framework of the Erasmus teaching staff exchange program between the University of Iceland and the University of Chieti-Pescara. He has published several papers concerning the relationship among landscape, identity and regional development in Iceland.

Recibido: 6 de Febrero de 2011

Aceptado: 12 de Abril de 2011 